\title{
GAMBARAN PENGETAHUAN REMAJA TENTANG HIV/AIDS DI PUSAT PENGEMBANGAN ANAK ID - 127 KELURAHAN RANOMUT MANADO
}

\author{
Stella M. Soselisa \\ Henry M. F. Palandeng \\ Lilian Andries \\ Bagian Ilmu Kedokteran Pencegahan Fakultas Kedokteran
Universitas Sam Ratulangi Manado
Email: stellasoselisa@yahoo.com
}

Abstract: AIDS is a collection of symptoms and infections that arise due to the disturbance of the body defence system. There were 24,482 AIDS cases recorded up to the end of March 2011 in 33 provinces in Indonesia. Data from the North Sulawesi Health Department showed that from 1997 until the end of 2010 the distribution of HIV/AIDS continued to increase. This study aimed to find out the understanding about HIV/AIDS in teenagers at the Children's Development Center ID-127 in Ranomut District, Manado. This was a descriptive study conducted by using a survey method. There were 65 samples of teenagers. The results showed that the teenagers' understanding about HIV/AIDS was still poor. Their answers about the cause of HIV/AIDS were 27.7\% correct; about the media of infection, $23 \%$ correct; about the signs and symptoms, $15.3 \%$ correct; about the prevention of HIV/AIDS, 75.3\% correct; about the stigma of HIV/AIDS, 63\% correct; about using the same utensils, 33.9\% correct; and about living in the same house, $49.1 \%$ correct. Conclusion: Among the teenagers at the Children's Development Center ID-127 in Ranomut District, Manado there was poor knowledge about the causes of HIV/AIDS, media of infection, and signs and symptoms; there was good knowledge about prevention of HIV/AIDS; as well as good knowledge about the stigma of HIV/AIDS; but poor knowledge about using the same utensils and living in the same house with HIV/AIDS patients.

Keywords: knowledge, teenagers, children development center, HIV/AIDS.

\begin{abstract}
Abstrak: AIDS adalah sekumpulan gejala dan infeksi (sindrom) yang timbul karena terganggunya sistem kekebalan tubuh manusia. Hingga akhir Maret 2011 tercatat 24.482 kasus di 33 provinsi di Indonesia. Data Dinas Kesehatan Sulawesi Utara (Dinkes Sulut) sejak tahun 1997 sampai akhir 2010 memperlihatkan distribusi penderita HIV/AIDS terus mengalami peningkatan. Penelitian ini bertujuan untuk mengetahui pengetahuan mengenai HIV/AIDS dari remaja di Pusat Pengembangan Anak ID-127 kelurahan Ranomut Manado. Penelitian ini bersifat deskriptif dan dilakukan melalui survei. Jumlah sampel yang diperoleh ialah 65 remaja. Hasil penelitian memperlihatkan bahwa pemahaman tentang HIV/AIDS dari para remaja masih kurang. Pengetahuan remaja tentang penyebab HIV/AIDS yang benar 27,7\%; tentang media penularan HIV/AIDS yang benar 23\%; tentang gejala-gejala HIV/AIDS yang benar 15,3\%; dan tentang pencegahan HIV/AIDS yang benar 75,3\%. Simpulan: Pada remaja di PPA ID-127 Kelurahan Ranomut Manado, pengetahuan tentang AIDS: masih kurang, mengenai penyebab HIV/AIDS, media penularan, dan gejala-gejala; baik, mengenai pencegahan HIV/AIDS; baik, mengenai stigma HIV/AIDS, dalam hal ini yaitu berjabat tangan dengan pengidap tidak dapat tertular; dan kurang, mengenai tidak dapat tertular bila memakai peralatan yang sama dengan pengidap dan tinggal serumah dengan pengidap.
\end{abstract}

Kata kunci: pengetahuan, remaja, pusat pengembangan anak, HIV/AIDS. 
Acquired Immune Deficiency Syndrome (AIDS) dapat diartikan sebagai kumpulan gejala atau penyakit yang disebabkan oleh menurunnya kekebalan tubuh akibat terinfeksi oleh virus Human Immunodeficiency Virus (HIV) yang termasuk dalam famili retroviridae, yaitu virus yang melemahkan kekebalan tubuh manusia. ${ }^{1}$

HIV biasanya menyerang organ-organ vital sistem kekebalan manusia, seperti sel $\mathrm{T} \mathrm{CD}^{+}$, makrofag, dan sel dendritik baik secara langsung maupun tidak langsung sehingga sistem kekebalan tubuh tidak dapat berfungsi baik. Bila HIV telah membunuh sel $\mathrm{T}$ CD4 ${ }^{+}$hingga jumlahnya menyusut kurang dari 200 per mikroliter $(\mu \mathrm{L})$ darah, maka kekebalan di tingkat sel akan hilang, dan akibatnya ialah kondisi yang disebut AIDS. Infeksi akut HIV akan berlanjut menjadi infeksi laten klinis, kemudian timbul gejala infeksi HIV awal, dan akhirnya AIDS, yang dapat diidentifikasi dengan memeriksa jumlah sel $\mathrm{T}$ $\mathrm{CD}^{+}$di dalam darah serta adanya infeksi tertentu. ${ }^{3}$

Djoerban (1983) melakukan penelitian terhadap 30 waria di Jakarta, dan dinyatakan dua diantaranya. Pada Kongres Persatuan Ahli penyakit Dalam Indonesia (KOPAPDI) VI tahun 1984, dilaporkan bahwa dari 15 orang yang diperiksa, tiga memenuhi kriteria minimal untuk didiagnosis AIDS. Tahun 1985, Djoerban menyatakan bila penyakit AIDS sampai menyerang masyarakat akan sulit dicegah, yang dibenarkan oleh Menteri Kesehatan yang menyatakan adanya kemungkin AIDS sudah masuk ke Indonesia. ${ }^{2}$

Penelitian ini bertujuan untuk mengetahui gambaran pengetahuan remaja tentang penyebab, media penularan, gejala, pencegahan, dan stigma penularan tentang HIV/AIDS di PPA ID-127 Kelurahan Ranomut Manado.

\section{HASIL PENELITIAN}

Dari 80 remaja berusia 11-15 tahun di Pusat Pengembangan Anak (PPA) ID-127 yang terdaftar hingga bulan Januari 2012, didapatkan 65 sampel.

\section{Karakteristik responden}

Pada Tabel 1 dilihat bahwa kelompok responden terbesar berusia 12 tahun sebesar $52,3 \%$, sedangkan responden terkecil berusia 15 tahun sebesar 3,1\%.

Berdasarkan jenis kelamin, responden terbanyak ialah perempuan, sebesar 53,9\% (Tabel 2).

Distribusi responden berdasarkan agama menunjukkan terbesar beragama Kristen Protestan sebesar 95,4\% dan yang terkecil beragama Katholik sebesar 4,6\% (Tabel 3).

Pada Tabel 4 terlihat bahwa kelompok responden terbanyak yang tinggal dengan orang tua sebesar 92,3\% sedangkan yang dengan saudara 7,7\%.

Tabel 1. Distribusi responden berdasarkan usia.

\begin{tabular}{ccc}
\hline $\begin{array}{c}\text { Usia } \\
\text { (tahun) }\end{array}$ & $\mathbf{N}$ & $\mathbf{\%}$ \\
\hline 11 & 6 & 9,3 \\
12 & $\mathbf{3 4}$ & $\mathbf{5 2 , 3}$ \\
13 & 15 & 23 \\
14 & 8 & 12,3 \\
15 & 2 & 3,1 \\
\hline Jumlah & 65 & 100 \\
\hline
\end{tabular}

Tabel 2. Distribusi responden berdasarkan jenis kelamin.

\begin{tabular}{ccc}
\hline $\begin{array}{c}\text { Jenis } \\
\text { kelamin }\end{array}$ & $\mathbf{N}$ & $\mathbf{\%}$ \\
\hline Laki-laki & 30 & 46,1 \\
Perempuan & $\mathbf{3 5}$ & $\mathbf{5 3 , 9}$ \\
\hline Jumlah & 65 & 100 \\
\hline
\end{tabular}

Tabel 3. Distribusi responden berdasarkan agama.

\begin{tabular}{lcc}
\hline \multicolumn{1}{c}{ Agama } & N & $\mathbf{\%}$ \\
\hline Kristen Protestan & $\mathbf{6 2}$ & $\mathbf{9 5 , 4}$ \\
Kristen Katholik & 3 & 4,6 \\
\hline Jumlah & 65 & 100 \\
\hline
\end{tabular}


Tabel 4. Distribusi responden berdasarkan tempat tinggal dengan orang tua atau saudara.

\begin{tabular}{llc}
\hline Tempat tinggal & $\mathbf{N}$ & $\mathbf{\%}$ \\
\hline Orang Tua & $\mathbf{6 0}$ & $\mathbf{9 2 , 3}$ \\
Saudara & 5 & 7,7 \\
\hline Jumlah & 65 & 100 \\
\hline
\end{tabular}

\section{Pengetahuan responden}

Tabel 5 menunjukkan bahwa kelompok terbesar yaitu yang pernah mendengar tentang HIV/AIDS sebesar 72,3\% sedangkan kelompok terkecil yang memilih tidak pernah mendengar tentang HIV/AIDS sebesar $27,7 \%$.

Tabel 6 memperlihatkan sumber informasi tentang HIV/AIDS dimana kelompok responden terbesar memilih jawaban nomor 1 (orang tua) sebanyak 43\% dan yang paling sedikit responden memilih jawaban nomor 10 (perawat) sebanyak 9,23\%.

Tabel 5. Pernah tidaknya mendengar tentang HIV/AIDS.

\begin{tabular}{ccc}
\hline $\begin{array}{c}\text { Pernah mendengar } \\
\text { tentang HIV/AIDS }\end{array}$ & $\mathbf{N}$ & $\mathbf{\%}$ \\
\hline Ya & $\mathbf{4 7}$ & $\mathbf{7 2 , 3}$ \\
Tidak & 18 & 27,7 \\
\hline Jumlah & 65 & 100 \\
\hline
\end{tabular}

Tabel 6. Sumber informasi tentang HIV/AIDS.

\begin{tabular}{llc}
\hline Sumber informasi & $\mathbf{N}$ & $\mathbf{\%}$ \\
\hline Orang Tua & $\mathbf{2 8}$ & $\mathbf{4 3}$ \\
Guru & 25 & 38,4 \\
Dokter & 25 & 38,4 \\
Televisi & 23 & 35,5 \\
Internet & 20 & 30,7 \\
Majalah kesehatan & 16 & 24,6 \\
Teman & 14 & 21,5 \\
Radio & 14 & 21,5 \\
Surat kabar & 12 & 18,4 \\
Perawat & 6 & 9,2 \\
\hline
\end{tabular}

Tabel 7 memperlihatkan bahwa kelompok responden terbesar yaitu yang memilih AIDS merupakan penyakit menular seksual sebesar 35,5\% dan kelompok responden terkecil yaitu yang memilih AIDS sebagai penyakit pada golongan masyarakat tertentu sebesar 6,15\%.

Pada Tabel 8 dapat dilihat kelompok responden terbesar yang memilih penyebab AIDS ialah tidak tahu sebesar 41,6\% dan kelompok responden terkecil memilih kuman AIDS sebesar 12,3\%.

Tabel 7. Definisi AIDS.

\begin{tabular}{llcc}
\hline No & \multicolumn{1}{c}{ Definisi AIDS } & N & $\mathbf{\%}$ \\
\hline 1. & $\begin{array}{l}\text { Suatu kumpulan geja- } \\
\text { la akibat penurunan }\end{array}$ & 16 & 24,7 \\
& $\begin{array}{l}\text { sistem kekebalan tubuh } \\
\text { 2enyakit menular }\end{array}$ & $\mathbf{2 3}$ & $\mathbf{5 3 , 3}$ \\
& $\begin{array}{l}\text { seksual } \\
\text { Penyakit pada go- }\end{array}$ & 4 & 6,1 \\
& $\begin{array}{l}\text { longan masyarakat } \\
\text { Penyakit turunan }\end{array}$ & 0 & 0,00 \\
5. & Tidak tahu & 22 & 33,9 \\
\hline & Jumlah & 65 & 100 \\
\hline
\end{tabular}

Tabel 8. Penyebab AIDS.

\begin{tabular}{lll}
\hline Penyebab AIDS & $\mathbf{N}$ & $\mathbf{\%}$ \\
\hline Kuman AIDS & 8 & 12,3 \\
Virus HIV & 18 & 27,7 \\
$\begin{array}{l}\text { Penurunan sistem ke- } \\
\text { kebalan tubuh }\end{array}$ & 12 & 18,4 \\
Tidak tahu & $\mathbf{2 7}$ & $\mathbf{4 1 , 6}$ \\
\hline Jumlah & 65 & 100 \\
\hline
\end{tabular}

Pada Tabel 9 dapat dilihat kelompok responden terbesar yaitu yang memilih siapa saja sebesar 38,4\% dan kelompok responden terkecil yaitu yang memilih hanya pekerja seks komersial sebesar 6,1\%.

Tabel 9. Siapa saja dapat tertular HIV/AIDS.

\begin{tabular}{|c|c|c|}
\hline $\begin{array}{l}\text { Yang dapat tertular } \\
\text { HIV/AIDS }\end{array}$ & $\mathbf{N}$ & $\%$ \\
\hline Siapa saja & 25 & 38,4 \\
\hline Hanya pekerja seks komersial & 4 & 6,1 \\
\hline $\begin{array}{l}\text { Hanya pengguna narkoba } \\
\text { suntik }\end{array}$ & 5 & 6,7 \\
\hline $\begin{array}{l}\text { Orang yang suka berganti- } \\
\text { ganti pasangan }\end{array}$ & 9 & 29,2 \\
\hline Tidak tahu & 2 & 18,4 \\
\hline Jumlah & 65 & 100 \\
\hline
\end{tabular}


Dari Tabel 10 dapat dilihat kelompok responden terbesar yaitu yang memilih media HIV melalui alat kelamin sebesar $41,5 \%$ dan responden yang terkecil yaitu yang memilih media penularan melalui air seni dan tinja sebesar 1,5\%.

Tabel 10. Media penularan HIV.

\begin{tabular}{cllc}
\hline No & Media penularan HIV & N & \% \\
\hline 1 & Melalui alat kelamin & 27 & 41,5 \\
2 & $\begin{array}{l}\text { Dalam cairan tubuh se- } \\
\text { perti: darah, semen, dan }\end{array}$ & & 23 \\
& & \\
& cairan vagina. & \\
3 & Dalam air seni dan tinja & 1 & 1,5 \\
4 & Melalui kulit & 5 & 7,6 \\
5 & Melalui handuk, pakaian & 17 & 26,1 \\
& dalam dan pakaian bekas & & \\
\hline \multicolumn{1}{c}{ Jumlah } & 65 & 100 \\
\hline
\end{tabular}

Dari Tabel 11 dapat dilihat kelompok responden terbesar yaitu yang tidak tahu gejala-gejala AIDS sebesar 84,6\% dan kelompok responden yang terkecil yaitu yang tahu gejala-gejala AIDS sebesar 15,4\%.

Tabel 11. Tahu tidaknya tentang gejala AIDS.

\begin{tabular}{ccc}
\hline Gejala-gejala AIDS & $\mathbf{N}$ & $\mathbf{\%}$ \\
\hline Ya & 10 & 15,4 \\
Tidak & 55 & 84,6 \\
\hline Jumlah & 65 & 100 \\
\hline
\end{tabular}

Dari Tabel 12 dapat dilihat kelompok responden terbesar yaitu memilih menghindari pergaulan bebas sebesar 41,6\% dan responden yang terkecil yaitu memakai kondom saat melakukan hubungan seksual sebesar $4,6 \%$.

Dari Tabel 13 dapat dilihat kelompok responden terbesar yaitu yang pernah mendengar kasus AIDS di Sulawesi Utara sebesar 52,3\% dan kelompok terkecil yaitu yang tidak pernah mendengar kasus AIDS di Sulawesi Utara sebesar 47,7\%.

Dari Tabel 14 dapat dilihat kelompok responden terbesar yaitu yang memilih jawaban HIV/AIDS tidak dapat disembuhkan sebesar 72,3\% dan yang responden terkecil yaitu yang memilih jawaban HIV/ AIDS dapat disembuhkan 27,7\%.

Tabel 12. Distribusi berdasarkan pengetahuan responden terhadap pencegahan penularan HIV/AIDS.

\begin{tabular}{llrl}
\hline No & \multicolumn{1}{c}{$\begin{array}{c}\text { Pencegahan penularan } \\
\text { HIV/AIDS }\end{array}$} & N & \% \\
\hline 1 & $\begin{array}{l}\text { Tidak melakukan hubungan } \\
\text { seksual sebelum menikah }\end{array}$ & 15 \\
2 & $\begin{array}{l}\text { Menghindari pergaulan bebas } \\
\text { Tidak menggunakan NAR- }\end{array}$ & 27 & 41,6 \\
3 & 6,1 \\
& $\begin{array}{l}\text { KOBA lewat jarum suntik } \\
\text { Memakai kondom saat } \\
\text { melakukan hubungan seksual }\end{array}$ & 3 & 4,6 \\
5 & 16 & 24,7 \\
\hline Tidak tahu & 65 & 100 \\
\hline \multicolumn{1}{c}{ Jumlah } & &
\end{tabular}

Tabel 13. Pernah tidaknya mendengar kasus AIDS di Sulawesi Utara.

\begin{tabular}{ccc}
\hline $\begin{array}{l}\text { Pernah mendengar kasus } \\
\text { AIDS di Sulawesi Utara }\end{array}$ & $\mathbf{N}$ & $\mathbf{\%}$ \\
\hline Ya & 34 & 52,3 \\
Tidak & 31 & 47,7 \\
\hline Jumlah & 65 & 100 \\
\hline
\end{tabular}

Tabel 14. Apakah HIV/AIDS dapat disembuhkan.

\begin{tabular}{cll}
\hline $\begin{array}{l}\text { AIDS dapat disem- } \\
\text { buhkan }\end{array}$ & $\mathbf{N}$ & $\mathbf{\%}$ \\
\hline Ya & 18 & 27,7 \\
Tidak & 47 & 72,3 \\
\hline Jumlah & 65 & 100 \\
\hline
\end{tabular}

Dari Tabel 15 dapat dilihat kelompok responden terbesar yaitu berjabat tangan tidak dapat menimbulkan penularan HIV/AIDS sebesar 63\% dan yang terkecil yaitu yang memilih berjabat tangan dapat tertular HIV/AIDS sebesar 37\%.

Dari Tabel 16 dapat dilihat kelompok responden terbesar yaitu responden yang berpendapat akan tertular apabila bertukar pakaian dengan penderita sebesar 50,8\% dan responden terkecil memilih tidak akan tertular sebesar $49,2 \%$. 
Tabel 15. Distribusi responden tentang apakah berjabat tangan dengan penderita dapat tertular.

\begin{tabular}{lcc}
\hline $\begin{array}{l}\text { Berjabat tangan dengan } \\
\text { penderita } \\
\text { tertular }\end{array}$ & $\mathbf{N}$ & $\mathbf{\%}$ \\
\hline Ya & & \\
Tidak & 24 & 37 \\
\hline \multicolumn{1}{c}{ Jumlah } & 41 & 63 \\
\hline
\end{tabular}

Tabel 16. Distribusi pendapat responden apabila bertukar pakaian dengan penderita apakah akan tertular.

\begin{tabular}{ccc}
\hline $\begin{array}{l}\text { Bertukar pakaian dengan } \\
\text { penderita dapat tertular }\end{array}$ & $\mathbf{N}$ & $\mathbf{\%}$ \\
\hline Ya & 33 & 50,9 \\
Tidak & 32 & 49,1 \\
\hline Jumlah & 65 & 100 \\
\hline
\end{tabular}

Dari Tabel 17 dapat dilihat kelompok responden terbesar yaitu responden yang berpendapat akan tertular HIV/AIDS apabila memakai peralatan makanan bersama sebesar $66,1 \%$ dan kelompok responden terkecil yang memilih tidak tertular sebesar 33,9\%.

Tabel 17. Distribusi memakai peralatan makanan yang sama dengan penderita, dapat tertular HIV/AIDS.

\begin{tabular}{cll}
\hline $\begin{array}{l}\text { Memakai peralatan ma- } \\
\text { kanan yang ama dengan } \\
\text { penderita dapat tertular }\end{array}$ & $\mathbf{N}$ & $\mathbf{\%}$ \\
\hline Ya & 43 & 66,1 \\
Tidak & 22 & 33,9 \\
\hline Jumlah & 65 & 100
\end{tabular}

Dari Tabel 18 dapat dilihat kelompok responden terbesar yaitu responden yang berpendapat akan tertular HIV/AIDS bila tinggal serumah dengan penderita sebesar $50,9 \%$ dan responden terkecil memilih tidak akan tertular sebesar 49,2\%.

Dari Tabel 19 dapat dilihat kelompok responden terbesar yaitu menyatakan tidak perlu dikeluarkan dari sekolah sebesar $61,5 \%$ sedangkan responden terkecil menyatakan perlu dikeluarkan dari sekolah sebesar 38,5\%.

Dari Tabel 20 dapat dilihat kelompok responden terbesar yaitu yang memilih jawaban kematian sebesar 63\% dan kelompok responden terkecil memilih jawaban dikucilkan dari masyarkat sebesar $33,8 \%$.

Tabel 18. Distribusi berdasarkan pendapat responden apabila tinggal serumah dengan penderita dapat tertular HIV/AIDS.

\begin{tabular}{lccc}
\hline $\begin{array}{l}\text { Tinggal serumah dengan } \\
\text { penderita dapat } \\
\text { HIV/AIDS }\end{array}$ & $\mathbf{N}$ & $\mathbf{\%}$ \\
tertular & & \\
\hline Ya & & 33 & 50,9 \\
Tidak & 32 & 49,1 \\
\hline Jumlah & 65 & 100 \\
\hline
\end{tabular}

Tabel 19. Distribusi responden perlu dikeluarkan/tidak, teman sekolah yang menderita HIV/AIDS.

\begin{tabular}{lccc}
\hline $\begin{array}{l}\text { Teman sekolah } \\
\text { HIV/AIDS perlu } \\
\text { kan atau tidak }\end{array}$ & $\begin{array}{c}\text { ter-kena } \\
\text { dikeluar- }\end{array}$ & $\mathbf{N}$ & $\mathbf{\%}$ \\
\hline Perlu & & \\
Tidak perlu & 25 & 38,5 \\
\hline \multicolumn{1}{c}{ Jumlah } & 40 & 61,5 \\
\hline
\end{tabular}

Tabel 20. Akibat dari HIV/AIDS.

\begin{tabular}{lcc}
\hline Akibat dari HIV/AIDS & N & $\mathbf{\%}$ \\
\hline Kematian & 41 & 63 \\
Menularkan pada bayi & 31 & 47,7 \\
Hidup menderita & 28 & 43 \\
Menderita akit kronis & 23 & 35,3 \\
Dikucilkan dari masya-rakat & 22 & 33,8 \\
\hline
\end{tabular}

\section{BAHASAN}

Pada penelitian ini didapatkan sebanyak 65 orang remaja/responden. Kelompok responden terbanyak berusia 12 tahun yaitu 34 responden (52,3\%) dan yang terkecil 15 tahun yaitu dua responden $(3,1 \%)$ (Tabel 1). Pada gambaran jenis kelamin terdapat perbandingan yang hampir sama antara responden laki-laki sebanyak 30 responden (46,1\%) sedangkan perempuan sebanyak 35 responden (53,9\%) 
(Tabel 2). Kelompok responden terbanyak beragama Kristen Protestan sebanyak 62 responden (95,4\%), kemudian Kristen Katholik sebanyak tiga responden (4,6\%) (Tabel 3). Sebagian besar responden tinggal dengan orang tua, yaitu sebanyak 60 responden (92,3\%), dan yang tinggal dengan wali/saudara sebanyak lima responden $(7,7 \%)$ (Tabel 4$)$.

Pengetahuan tentang HIV/AIDS dari Tabel 5 diketahui bahwa terdapat 47 responden $(72,3 \%)$ sudah pernah mendengar tentang HIV/AIDS dan 18 (27,7\%) responden yang belum pernah mendengar tentang HIV/AIDS. Hal ini menunjukkan bahwa HIV/AIDS bukanlah hal yang baru. Sumber informasi mengenai HIV/AIDS terutama berasal dari orang tua (Tabel 6).

Dari Tabel 7 dapat diketahui bahwa dari keseluruhan responden, ternyata hanya 16 responden $(24,7 \%)$ yang mengetahui dengan benar tentang definisi AIDS yaitu sebagai kumpulan gejala-gejala akibat penurunan sistem kekebalan tubuh. Sebanyak 23 responden (35,3\%) menjawab AIDS sebagai penyakit menular seks, dan sebanyak 22 responden (33,9\%) memilih tidak tahu. Sebanyak empat responden $(6,1 \%)$ menjawab AIDS merupakan penyakit pada golongan masyarakat tertentu.

Dari Tabel 8 dapat diketahui bahwa yang mengetahui penyebab AIDS ialah 18 responden $(27,7 \%)$. Sebanyak 27 responden $(41,6 \%)$ memilih jawaban tidak tahu penyebab AIDS, 12 responden (18,4\%) yang menjawab penyebab AIDS ialah penurunan sistem kekebalan tubuh, dan sebanyak delapan responden (12,3\%) yang menjawab penyebab AIDS ialah kuman AIDS.

Dari Tabel 9 didapatkan pengetahuan responden tentang siapa saja yang tertular HIV/AIDS. Sebagian besar responden yaitu 25 responden $(38,4 \%)$ telah mengetahui bahwa setiap orang bisa tertular HIV/ AIDS. Sebanyak 19 responden (29,2\%) menjawab penularan HIV/AIDS ialah orang yang suka berganti-ganti pasangan, lima responden $(6,7 \%)$ menjawab penularan HIV/AIDS hanya pengguna narkoba suntik, dan empat responden (6,1\%) menjawab penularan HIV/AIDS hanya pekerja seks komersial.

Dari Tabel 10 diketahui bahwa sebagian besar responden tidak memahami dengan benar tentang media penularan HIV/AIDS. Sebanyak 15 responden (23\%) menjawab media penularannya di dalam cairan tubuh seperti: darah, semen dan cairan vagina. Sebanyak 27 responden (41,5\%) menjawab media penularannya melalui alat kelamin dan yang satu responden menjawab media penularannya dalam air seni dan tinja.

Dari Tabel 11 menunjukkan bahwa sebanyak 55 responden (84,62\%) tidak tahu gejala-gejala AIDS dan sebanyak 10 responden $(15,4 \%)$ tahu gejala-gejala AIDS.

Dari Tabel 12 di dapatkan bahwa pengetahuan responden tentang cara pencegahan HIV/ AIDS 27 responden (41,6\%) memilih jawaban menghindari pergaulan bebas dan sebanyak 15 responden (23\%) memilih jawaban tidak melakukan hubungan seksual sebelum menikah. Sebanyak 16 responden (24,6\%) memilih jawaban tidak tahu, empat responden (6,15\%) memilih jawaban tidak menggunakan narkoba lewat jarum suntik, dan tiga responden (4,6\%) memilih jawaban memakai kondom saat melakukan hubungan seksual.

Berdasarkan Tabel 13 dapat diketahui bahwa sebanyak 34 responden (52,3\%) memilih jawaban pernah mendengar adanya kasus HIV/AIDS di Sulawesi Utara sadangkan 31 responden (47,7\%) memilih jawaban tidak pernah mendengar kasus HIV/AIDS.

Dari Tabel 14 dapat diketahui bahwa hampir semua, yaitu 56 responden (86,15\%) tidak mengetahui bahwa sekarang telah ada pengobatan untuk HIV, walaupun memang belum terdapat obat yang mampu menyembuhkan.

Dari Tabel 15 dapat di lihat sikap responden terhadap apakah orang yang berjabat tangan dengan pengidap HIV/ AIDS akan tertular. Sebagian besar yaitu 63\% berpendapat tidak akan tertular HIV/AIDS karena penularan HIV/AIDS tidak melalui tangan kecuali bila terluka, 
sedangkan yang menjawab akan tertular sebesar 37\%.

Dari Tabel 16 sebagian besar responden berpendapat akan tertular HIV/ AIDS bila bertukar pakaian dengan pengidap HIV/AIDS yaitu sebanyak 33 responden (50,8\%), sedangkan sebanyak 32 responden $(49,2 \%)$ berpendapat tidak akan tertular HIV/AIDS bila bertukar pakaian dengan penderita HIV/AIDS.

Dari Tabel 17 sebagian besar responden berpendapat akan tetular HIV/AIDS bila memakai peralatan makanan yang sama dengan pengidap HIV/AIDS yaitu sebanyak 43 responden (66,1\%). Sebanyak 22 responden (33,9\%) berpendapat tidak akan tertular HIV/AIDS bila memakai peralatan makanan yang sama dengan pengidap HIV/ AIDS. Hal ini menunjukkan bahwa masih kurangnya pemahaman dari responden terhadap pengidap HIV/AIDS.

Dari Tabel 18 sebagian besar responden berpendapat akan tertular HIV/AIDS bila tinggal serumah dengan pengidap HIV/ AIDS yaitu sebanyak 33 responden (50,8\%). Sebanyak 32 responden (49,2\%) berpendapat tidak akan tertular HIV/AIDS bila tinggal serumah dengan pengidap HIV/AIDS. Hal ini menunjukkan bahwa pemahaman responden masih kurang terhadap pengidap HIV/AIDS termasuk stigma dalam hubungan-hubungan sosial.

Dari Tabel 19 sikap responden terhadap teman yang terkena HIV/AIDS sebanyak 40 responden $(61,5 \%)$ menyatakan tidak perlu, sedangkan 25 responden (38,5\%) menyatakan perlu dikeluarkan dari sekolah.

Tabel 20 mengenai responden yang telah mengetahui akibat dari HIV/AIDS seperti kematian, menderita sakit kronis, hidup menderita, dikucilkan dari masyarakat dan menularkan pada bayi. Sebanyak 19 responden (29,23\%) memilih salah satu jawaban di atas dan sisanya memilih jawaban bervariasi antara dua sampai lima jawaban. Hal ini menunjukkan bahwa pengetahuan responden tentang akibat HIV/AIDS sudah baik.

Sebanyak 38,3\% dari keseluruhan responden menjawab benar definisi AIDS; $13,3 \%$ menjawab benar gejala-gejala HIV/
AIDS; 34,3\% menjawab benar tentang cara penularan HIV/AIDS; 24,6\% menjawab benar tentang cara pencegahan penularan HIV/AIDS; 25\% menjawab benar tentang dampak dari HIV/AIDS; dan 81,3\% menjawab benar tentang siapa saja yang mungkin tertular HIV/AIDS.

Hasil wawancara dengan remaja di Pusat Pengembangan Anak ID-127 di Kelurahan Ranomut Manado menunjukkan pengetahuan responden yang masih kurang baik. Hal ini mungkin dipengaruhi oleh kurangnya media informasi, penyuluhan atau seminar kesehatan yang membahas tentang HIV/AIDS.

\section{SIMPULAN}

Dari hasil penelitian dapat disimpulkan bahwa pengetahuan remaja di PPA ID-127 kelurahan Ranomut Manado mengenai penyebab HIV/AIDS, media penularan, dan gejala-gejala masih kurang sedangkan pengetahuan mengenai pencegahan HIV/ AIDS baik. Pengetahuan stigma mengenai HIV/AIDS, dalam hal ini yaitu berjabat tangan dengan pengidap tidak dapat tertular ialah baik, sedangkan memakai peralatan yang sama dengan pengidap tidak dapat tertular dan tinggal serumah dengan pengidap ialah kurang.

\section{DAFTAR PUSTAKA}

1. Djoerban Z, Djauzi S. HIV/AIDS di Indonesia. In: Sudoyo A, Setiyohadi B, Alwi I, Simadibrata M, Setiati S, editors. Buku Ajar Ilmu Penyakit Dalam Jilid III [Edisi Keempat]. Jakarta: Departemen Ilmu Penyakit Dalam FKUI, 2006; p.1803.

2. Yayasan Spiritia. Sejarah HIV di Indonesia [homepage on the Internet]. 2009 [update 2009 Juni 5; cited 2011 Okt 3]. Available from: URL: http://Spiritia. or.id./art/pdf/a1040.pdf.

3. Lan VM. Virus immunodefisiensi manusia (HIV) dan sindrom immunodefisiensi didapat (AIDS). In: Price SA, Wilson LM, editors. Patofisiologi Konsep Klinis Proses-Proses Penyakit Jilid I [Edisi Keenam]. Jakarta: Kedokteran EGC, 2006; p.227. 